\title{
The isolation of influenza viruses
}

\author{
P. G. HIGGINS ${ }^{1}$ AND EILEEN M. ELLIS
}

From the Virus Laboratory, Public Health Laboratory Service, 86 Dyer Street, Cirencester, Glos

SYNOPSIS Of 129 strains of the Hong Kong variant of influenza A2 virus isolated from 176 respiratory infections, $105(81.4 \%)$ were isolated in tissue culture, the remainder being detected only by the inoculation of fertile hen's eggs. Organ cultures of chick embryo trachea were at least as sensitive as monkey kidney tissue culture for the isolation of this virus but organ cultures of human embryonic ciliated epithelium were much less efficient. The reverse was true for strains of influenza B virus studied in 1970 and 1971 when eggs and chick embryo tracheal organ culture were of little value and organ cultures of human embryonic ciliated epithelium and monkey kidney tissue cultures were the systems of choice.

The laboratory diagnosis of influenza is considered to be easier than that of many other infections with respiratory viruses. However, the inability to confirm a clinical diagnosis of influenza in a number of cases during an outbreak of infections with the Hong Kong (HK) variant of influenza virus A2 led to an assessment of methods other than tissue culture for the isolation of influenza $A$ virus. The same techniques were compared for their efficiency in the isolation of influenza B virus during outbreaks in 1970 and 1971.

\section{Materials and Methods}

Specimens for virus isolation consisted of a nose and a throat swab taken from patients with acute respiratory illness during an outbreak of influenza A2 virus infections which occurred in December 1969 and January 1970 and two outbreaks of infections with influenza B virus during April and May 1970 and again between January and March 1971. These swabs were broken off in a bijou of transport medium and delivered to the laboratory on melting ice. The specimens were examined in secondary cultures of monkey kidney, the Bristol line of HeLa cells, the WI38 strain of human diploid fibroblasts, and primary cultures of human embryo kidney. A separate throat swab from each case was examined on a blood agar plate for $\beta$-haemolytic streptococci and specimens from children under 16 years of age were inoculated into suckling mice.

'Present address: Virus Reference Laboratory, Central Public Health Laboratory, Colindale, London, NW9 5HT.

Received for publication 29 December 1971.
The attempted isolation of influenza virus by the use of fertile hen's eggs was accomplished by inoculating $0.2 \mathrm{ml}$ of the specimen into the amniotic cavity of each of three 11-day-old embryos. The amniotic fluid, harvested after three days' incubation at $36^{\circ} \mathrm{C}$, was tested for the presence of haemagglutinin and inoculated into cultures of monkey kidney which were subsequently maintained for 10 days and tested for haemadsorption at five-day intervals. No blind passage of amniotic fluid was performed.

Organ cultures of human embryonic nasal and tracheal epithelium and 17-20-day-old chick embryo trachea were prepared as described by other workers (Butler, 1969; Cherry and Taylor-Robinson, 1970; Votava and Tyrrell, 1970) and maintained in serumfree medium in $6 \times 5 / 8$ in. test tubes which were rolled at $33^{\circ} \mathrm{C}$. The organ culture fluids were harvested every two or three days and passed into secondary cultures of monkey kidney, which were then maintained for 10 days and tested for haemadsorption at five-day intervals. In addition fluids from human organ cultures were given one blind passage and then tested in cultures of human embryo kidney and WI38. Organ culture fluids which were submitted to electron microscopy had a total of four passes in organ culture. The fourth pass organ culture fluid was spun at $60,000 \mathrm{~g}$ for 30 minutes, the pellet re-suspended in a few drops of distilled water, and applied to a formvar-carbon-coated grid, where it was stained with $2 \%$ phosphotungstic acid at $p \mathbf{H}$ 6.9. The grids were then examined in a Phillips 200 electron microscope. 
Results

Specimens were received from 176 cases between the first and last isolations of influenza A2 virus during the winter of $1969 / 70$. Ninety-four specimens were from males and 82 from females. Eighteen of the illnesses occurred in children under 5, 33 in children between 5 and 15 years of age, and 125 were in adults. One hundred strains of influenza A2 were detected in cultures of monkey kidney and a further five strains were isolated in human embryo kidney but not in monkey kidney. In two other cases a rhinovirus was isolated and Strep. pyogenes was cultured from the throat swab of a third. By the standard methods of blood agar plate, tissue culture, and suckling mice, a probable causal agent had been identified in 108 of the 176 cases studied.

Because of illness amongst the practitioners many of the cases had been swabbed by the laboratory staff which made us aware that we were unable to isolate influenza virus from good material taken during the acute phase of what was, clinically, typical influenza. We were prompted, therefore, to attempt to isolate influenza virus from the remaining negative specimens by the inoculation of fertile hen's eggs, and from the 68 specimens $24(35.2 \%)$ strains of influenza A2 were isolated. Of the 129 strains of influenza A2 virus eventually isolated, $100(77.5 \%)$ were isolated in monkey kidney, a further five $(3.9 \%)$ in human embryo kidney, and $24(18.6 \%)$ in fertile hen's eggs.

In an attempt to prove the aetiology in the remaining 44 illnesses the specimens from these cases were examined in cultures of human embryonic ciliated epithelium. Three strains of rhinovirus were isolated and although 17 of the remaining 41 specimens were given further passages in organ culture and examined by electron microscopy no evidence of coronavirus infections was obtained. The clinical and virological diagnoses of the 176 cases studied are shown in Table I which also illustrates that even after quite extensive investigation almost a quarter $(23.3 \%)$ of the illness occurring in an influenza epidemic remained virologically unconfirmed.

Many laboratories rely on tissue culture alone for the isolation of influenza viruses as they can detect a much wider range of viruses than fertile hen's eggs which require different techniques for their use. Organ cultures in tissue culture tubes are more readily acceptable in the diagnostic laboratory, and, with this in mind, comparative studies using organ cultures of human embryonic ciliated epithelium and chick embryo tracheal cultures were undertaken. Eight specimens, previously shown to contain influenza $\mathrm{A} 2$ virus by the inoculation of eggs but negative in tissue culture, were inoculated after storage at $-40^{\circ} \mathrm{C}$ into eggs and cultures of human

\begin{tabular}{|c|c|c|}
\hline Number & Clinical Illness & Agents Isolated \\
\hline 143 & Influenza & \multirow{9}{*}{$\begin{aligned} & 112 \text { Influenza } A 2 \text { virus } \\
& 7 \text { Influenza A2 virus } \\
& 2 \text { Influenza A2 virus } \\
& 4 \text { Rhinoviruses } \\
& 2 \text { Influenza A2 virus } \\
& 1 \text { Influenza virus A2 } \\
& 1 \text { Influenza virus A2 } \\
& 1 \text { Influenza virus A2 } \\
& 1 \text { Rhinovirus } \\
& 3 \text { Influenza A2 virus } \\
& 1 \text { Str. pyogenes }\end{aligned}$} \\
\hline 10 & Tracheitis & \\
\hline 7 & Colds & \\
\hline 6 & Pharyngitis & \\
\hline 2 & Croup & \\
\hline$\overline{1}$ & Bronchit is & \\
\hline 1 & Bronchiolitis & \\
\hline 1 & Pneumonia & \\
\hline 5 & Unknown & \\
\hline \multirow[t]{3}{*}{176} & & \multirow{3}{*}{$\begin{array}{l}129 \text { Influenza A2 virus }{ }^{1} \\
5 \text { Rhinoviruses }{ }^{2} \\
1 \text { Str. pyogenes }\end{array}$} \\
\hline & & \\
\hline & & \\
\hline
\end{tabular}

Table I Isolations from 176 cases of acute respirator infections between 5 November 1969 and 8 January 1970 i

${ }^{1}$ Herpes simplex virus also isolated from four specimens.

${ }^{2}$ Str. pyogenes also isolated from one specimen.

nasal epithelium. All eight specimens yielded influenza virus by egg inoculation but only two werळ detected by the use of human nasal epithelium. It was thought that influenza virus may multiply bette in the human trachea than the nose so 16 specimens, stored at $-40^{\circ} \mathrm{C}$ but shown to contain influenza $A B$ when originally inoculated into monkey kidnes cultures, were inoculated in parallel into orgas cultures of human embryonic nasal epitheliumo human embryonic tracheal organ cultures, and orga疋 cultures of chick embryo trachea. Little differenc $\overrightarrow{\vec{E}}$

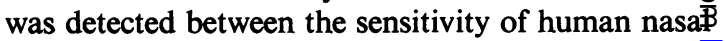
and human tracheal organ cultures as influenza virus was isolated from eight and nine out of the $1 \overline{8}$. specimens respectively. However, 14 of the 16: specimens yielded influenza A virus after inoculation of organ cultures of chick embryo trachea.

A comparison between monkey kidney culturesi fertile hen's eggs, and chick embryo tracheal organ cultures was undertaken with eight specimenso stored for several months at $-40^{\circ} \mathrm{C}$, which ha been shown to contain influenza $\mathrm{A} 2$ virus by the inoculation of eggs but not of tissue culture? Unfortunately only one specimen yielded influenza virus, again by egg inoculation, and the comparables monkey kidney and chick embryo tracheal culture? were both negative. A half $\log _{10}$ dilution series of aff HK virus suspension grown in monkey kidney tissue culture was tested in these three systems. The influenza virus was demonstrated in all cultures inoculated with dilutions from $10^{\circ}$ to $10^{-2}$ inclusive but only in eggs was influenza virus recovered ap lower concentrations and it could be detected up to dilution of $10^{-4}$. The findings in comparing differen methods for the isolation of influenza $\mathrm{A} 2$ virus are summarized in Table II. 


\begin{tabular}{|c|c|c|c|c|c|}
\hline & $\begin{array}{l}\text { Monkey Kidney } \\
\text { Tissue Culture }\end{array}$ & $\begin{array}{l}\text { Fertile } \\
\text { Hen's Eggs }\end{array}$ & $\begin{array}{l}\text { Human Nasal } \\
\text { Organ Culture }\end{array}$ & $\begin{array}{l}\text { Human Tracheal } \\
\text { Organ Culture }\end{array}$ & $\begin{array}{l}\text { Chick Tracheal } \\
\text { Organ Culture }\end{array}$ \\
\hline $\begin{array}{l}\text { Eight specimens positive only in eggs on } \\
\text { original testing } \\
\text { Sixteen specimens positive in monkey kidney }\end{array}$ & NT & $8 / 8$ & $2 / 8$ & NT & NT \\
\hline $\begin{array}{l}\text { on original testing } \\
\text { Titre of HK influenza A2 virus suspension }\end{array}$ & $\begin{array}{l}\text { NT } \\
10^{2}\end{array}$ & $\begin{array}{l}\text { NT } \\
10^{4}\end{array}$ & $\begin{array}{l}8 / 16 \\
\text { NT }\end{array}$ & $\begin{array}{l}9 / 16 \\
\text { NT }\end{array}$ & $\begin{array}{l}14 / 16 \\
10^{2}\end{array}$ \\
\hline
\end{tabular}

Table II Comparison of various systems for the isolation of influenza A2 virus

NT $=$ not tested.

Specimens stored at $-40^{\circ} \mathrm{C}$.

\begin{tabular}{lllll}
\hline & $\begin{array}{l}\text { Monkey Kidney } \\
\text { Tissue Culture }\end{array}$ & $\begin{array}{l}\text { Fertile } \\
\text { Hen's Eggs }\end{array}$ & $\begin{array}{l}\text { Human } \\
\text { Organ Culture }\end{array}$ & $\begin{array}{l}\text { Chick Tracheal } \\
\text { Organ Culture }\end{array}$ \\
\hline $\begin{array}{l}\text { Twelve specimens positive in monkey kidney on original testing } \\
1970\end{array}$ & $5 / 12$ & $0 / 12$ & $\mathrm{NT}$ & $3 / 12$ \\
$\begin{array}{l}\text { Twelve specimens negative in monkey kidney on original testing } \\
1970\end{array}$ & $1 / 12$ & $0 / 12$ & $\mathrm{NT}$ & $0 / 12$ \\
$\begin{array}{l}\text { Twenty-four specimens positive in monkey kidney on original } \\
\text { testing 1971 }\end{array}$ & $10 / 24$ & $\mathrm{NT}$ & $\mathrm{NT}$ & $1 / 24$ \\
$\begin{array}{l}\text { Eleven specimens positive in monkey kidney on original testing } \\
1971^{3}\end{array}$ & $1 / 11$ & $\mathrm{NT}$ & $2 / 11$ & $0 / 11$ \\
$\begin{array}{l}\text { Fourteen specimens positive in monkey kidney on original } \\
\text { testing 1971 }\end{array}$ & $9 / 14$ & $\mathrm{NT}$ & $10 / 14$ & $0 / 14$ \\
\hline
\end{tabular}

Table III Comparison of various systems for the isolation of influenza $B$ virus.

NT $=$ not tested

Specimens stored at $-40^{\circ} \mathrm{C}$ except ${ }^{2}$ stored at $-20^{\circ} \mathrm{C}$.

INFLUENZA B VIRUS

Because outbreaks of influenza B virus infections are seldom as pure as those with influenza $A$ virus no detailed study of all the illness occurring during outbreaks in 1970 and 1971 was undertaken. However, during these two outbreaks comparative studies were performed in an attempt to assess the sensitivity of fertile hen's eggs and human and chick embryo organ cultures for the isolation of influenza $B$ virus compared with that of monkey kidney tissue cultures. Twelve specimens, stored at $-40^{\circ} \mathrm{C}$ but shown to contain influenza $B$ virus when originally studied in tissue culture, were tested in monkey kidney cultures, fertile hen's eggs, and chick embryo tracheal organ cultures. Influenza B virus was isolated from five specimens in monkey kidney, from three in chick embryo tracheal culture, but none from eggs. A further 12 specimens previously negative on tissue culture examination were again examined, after storage, in these three systems. One strain of influenza B virus was isolated in monkey kidney tissue culture but not in the other two systems. Because of the inability to isolate influenza $B$ virus in eggs, 24 known positive specimens obtained in 1971 were re-examined in monkey kidney and chick embryo tracheal organ culture only. In 10 instances the virus was re-isolated in monkey kidney but only one was recovered by the use of chick embryo tracheal organ cultures. Another 11 positive specimens which had been stored at $-20^{\circ} \mathrm{C}$ were reexamined in the two systems but only one specimen yielded influenza virus; that in monkey kidney and not in chick embryo tracheal organ culture. Although human embryo organ cultures appeared relatively insensitive to influenza $A 2$ their ability to isolate influenza B virus was compared with that of monkey kidney tissue culture and chick embryo tracheal organ culture using 14 of the 24 specimens previously shown to contain influenza $B$ virus and stored at $-40^{\circ} \mathrm{C}$ and 11 similar specimens stored at $-20^{\circ} \mathrm{C}$. From these 25 specimens virus was recovered from 10 in monkey kidney tissue culture, none in chick embryo tracheal culture, and 12 following the inoculation of human embryo organ culture. These findings are summarized in Table III.

\section{Discussion}

The relative sensitivity of monkey kidney tissue culture and eggs for the isolation of influenza virus probably depends on the strain of influenza which is studied. It would appear that the inoculation of fertile hen's eggs is a much more sensitive way of detecting the presence of the HK variant of influenza A2 virus than that of tissue culture, while the reverse is true of the strains of influenza B virus studied during 1970 and 1971. It is very much more difficult to account for the relative inefficiency of human embryo organ cultures in detecting the presence of the $\mathrm{HK}$ variant of influenza $\mathrm{A} 2$ virus. However, these findings are in agreement with the results obtained by Roome, Dickinson, and Caul 
(1971) who isolated 15 out of 17 strains of HK virus in tissue culture but only eight strains in human embryonic tracheal organ cultures. These workers also failed to detect, by the use of organ cultures, eight strains of respiratory syncytial virus isolated in tissue culture and some strains of enteroviruses, mumps virus, and even rhinoviruses have failed to grow in organ culture but have been isolated by the direct inoculation of tissue cultures (Higgins, Ellis, and Woolley, 1969). Human organ cultures are of comparable sensitivity to monkey kidney tissue culture for the isolation of the strain of influenza B virus studied, and earlier workers (Voltava and Tyrrell, 1970) have shown that the titre of influenza B virus in material from a patient was similar in monkey kidney tissue culture and human organ culture. Chick embryo tracheal organ cultures parallel the sensitivity of fertile hen's eggs for the isolation of influenza $B$ virus but would appear to be at least as sensitive as monkey kidney for the isolation of the $\mathrm{HK}$ variant of influenza $\mathrm{A} 2$ virus. Because chick embryo tracheal organ cultures can so readily be assimilated into the diagnostic laboratory working solely with tissue cultures it would be worth while comparing its efficiency with that of fertile hen's eggs in the isolation of influenza A virus from original specimens.

We wish to acknowledge the continuing help of the staff of the gynaecological wards at St Paul's Hospital, Cheltenham, and the Victoria Hospita? Swindon, and also to Dr H. E. M. Kay of the Royals. Marsden Hospital in providing foetal material.

We are grateful to Dr A. H. T. Robb-Smith of the Radcliffe Infirmary, Oxford, for providing facilities for electron microscopy and to $\mathrm{Mr} \mathrm{D}$. Jerrome for his excellent technical assistance.

This work was performed with the aid of a grant from the Medical Research Council.

References

Butler, M. (1969). Isolation and growth of mycoplasma in humas embryo trachea cultures. Nature (Lond.), 224, 605-606.

Cherry, J. D., and Taylor-Robinson, D. (1970). Large-quantity production of chicken embryo tracheal organ cultures and use. in virus and mycoplasma studies. Appl. Microbiol., 19, 658-662

Higgins, P. G., Ellis, Eileen M., and Woolley, D. A. (1969). A com parative study of the standard methods and organ culture fors the isolation of respiratory viruses. J. med. Microbiol., 2, 109-115.

Roome, A. P. C. H., Dickinson, Valerie, and Caul, E. O. (1971 Simplified organ cultures of human embryo trachea in the. diagnosis of viral respiratory disease of children. J. clin. Pathş
24, 487-490.

Votava, M., and Tyrrell, D. A. J. (1970). The possible value of certain cells for the propagation of respiratory viruses. Arch. ges.Viruse forsch., 29, 253-256. 